\title{
Development of Stoichiometry Module Based on Problem Solving for Grade X of High School Students
}

\author{
Annisa Ush Sholihah ${ }^{1^{*}}$, Latisma Dj. ${ }^{2}$, Jon Efendi ${ }^{3}$ \\ 1,2,3 Universitas Negeri Padang, Padang Indonesia \\ *Corresponding author, e-mail: annisaummuzara@gmail.com
}

\begin{abstract}
One of the learning materials which can be used to enhance student's understanding of stoichiometry is module based on problem solving. The background of this study is based on interviews to some students who have studied stoichiometry. They stated that the teaching materials used were less interesting and less involved students actively in understanding concept. The aim of this study is to produce learning module and then tested the validity, practicality, and effectiveness so that it can be used in chemistry learning. The type of this research is Research and Development (R\&D). Development model used is 4-D model (define, design, develop and disseminate). This module was validated by 4 experts and then was tested to 2 chemistry teachers and 31 students of X Science Grade of SMA N 5 Padang. The data show that this problem solving based module on stoichiometry which has been produced are valid, practical, and effective.
\end{abstract}

Keywords: Learning module, problem solving, stoichimetry materials

How to Cite: Sholihah, A. U., Dj, L., \& Efendi, J. (2017). Development of Stoichiometry Module Based on Problem Solving for Grade X of High School Students. International Journal of Research in Counseling and Education, 1(1), 1-9. DOI: https://doi.org/10.24036/005za0002

\section{Introduction}

Chemistry is a science that was originally acquired and developed based on experiments (inductive) but in subsequent development of chemistry also obtained and developed based on the theory (deductive). Chemistry is the science that finds answers to the question of what, why, and how natural phenomena relate to the composition, structure and properties, changes, dynamics, and energetic of matter. Therefore, chemical subjects in High School learn everything about the substance that covers the composition, structure and properties, dynamics, and energetic substances that involves skill and reasoning (Devi, 2015).

One of the chemistry materials taught in High School is Stoichiometry. Stoichiometry studies the quantitative aspects of chemical reactions. The quantitative aspect is obtained by measuring the mass, volume, quantity, and so on, which are related to the number of atoms, ions, molecules or chemical formulas and their interrelations in a chemical reaction. Stoichiometry is one of the basic materials in the chemistry subject which must be well understood by the students in order to understand the chemical calculation material at the next level. Solving stoichiometry questions requires understanding and good mathematical analytical skills.

The results of interviews with some high school students who have studied stoichiometry material obtained a conclusion that the teaching materials they used were less interesting less actively involve students in understanding the concept. Therefore, it takes a teaching material that can improve students understanding of the concept and not only used to confirm the concept, but it can attract student's interest to learn, and can make students active. In addition, the required teaching materials are teaching materials that have levels of three levels of chemical representation (macroscopic, microscopic, and symbolic and their relationships between the three). One of the teaching materials is a learning module based on problem solving. Problem Solving can be defined as a series of learning activities that emphasize the process of 
solving problems faced scientifically (Komariah, 2011). According Polya in Bilgin (2005), there are four basic steps how to solve the problem, that is: understanding the problem, devising a plan, carrying out the plan, looking back. These steps are also known as terms see, plan, do and check (Alfaris, 2014). The steps of problem solving learning become the benchmark for developing learning modules on stoichiometry.

Module is teaching materials that are arranged systematically with language easily understood by students, according to their age and level of knowledge so that they can learn independently with minimal guidance from teachers (Prastowo, 2012). Modules to be developed must pay attention to five characteristic a module that is self instruction, self contained, stand alone, adaptive, and user friendly (The Ministry of National Education [MNE]: 2008).

According to MNE (2008), the preparation of the module should produce a draft module that includes at least the following: module title, procedures or instructional activities to be followed by the student to study the modules, competencies or sub-competencies to be achieved after completing the module study, the objectives consisting of the final destination and the intermediate objectives achieved by the students after studying the module, the material containing which students must learn and understand, the questions, exercises, and or tasks that must be done or completed by the students, evaluations or assessments that measure the ability of students to understand the module and keys answer of the questions.

Problem solving module is one of printed materials that can be used to help the learning process. The development of this module in accordance with the rules applicable for the purpose of making the module can support the achievement of learning objectives.

\section{Method}

The type of research is Research and Development (R\&D). Research and development is a research used to produce a specific product and test the effectiveness of the product (Sugiyono, 2011). The development model used to develop the learning module is the four D models (4-D models) developed by Thiagarajan et al. (1974). This 4-D model consists of 4 main stages, namely: (1) define, (2) design, (3) develop and (4) disseminate.

Description of the activities at each step of the development of the 4D model is described as follows:

1. Define

The purpose of this stage is to define the requirements needed in learning. The steps taken at this step are front-end analysis, student analysis, task analysis, concept analysis, and learning objectives specification. The front-end analysis stage is interviewed of 10 high school students who have studied stoichiometry. The purpose of student analysis is to examine the characteristics of students as an illustration for designing teaching materials. In the task analysis conducted basic competence (BC) analysis. The concept analysis is the identification of the main concepts on stoichiometry material. The analysis of learning objectives, based on task analysis and concept analysis can be formulated learning objectives. This analysis is used as the basis for constructing the developed teaching materials.

2. Design

The purpose of this stage is to design problem solving module based on basic competence and subject matter according to curriculum 2013. At this stage a draft of learning modules is produced which is based on the Ministry of National Education (2008) which consists of: module title; describes the material contained in the module; procedures or instructional activities that learners must follow to learn modules; competence or sub-competence (indicator) to be achieved upon completion of studying modules; the goal consists of the ultimate goal and the goal between which the learner will achieve after studying the module; the material containing which the students must learn and understand; questions, exercises, and / or tasks to be performed or completed by students; evaluation or assessment that serves to measure the ability of students in mastering the module; key answer from problem.

3. Development

The purpose of this stage is to produce a revised of module based on problem solving. This stage consists of validity, revision and trial test. At this step, the assessment is done by the experts through validity test and product development test through practicality test on teachers and students. Revisions are also made based on input from each of the steps of the test conducted. Prior to the product trial, the product of learning module based on problem solving that was generated was validated by 4 experts 
(validators). However, previously the data collection instruments used, need to be validated first by 3 experts.

After the revision, a practicality test is performed. Practicality of learning module based on problem solving seen from the product of the product of limited trial results in the field regarding the practicality and implementation of developed products. Practicality data is obtained from the results of questionnaire analysis of chemistry teacher response and student response questionnaire.

4. Disseminate

This stage is divided into three steps, namely: validation testing, packagings, diffusion and adoption. In validation testing, products that have been revised and declared valid at the development stage are then implemented on the real target by performing the effectiveness test. The effectiveness of problem solving module in this study is seen from the result of learning and student learning activity in class. Learning outcomes of students done by providing tests on the cognitive domain. Result of this study involves the learning outcomes after using the developed module. to assess the activity of the students is done by providing student activity observation sheet to the observer.

The dissemination has been done in this study is limited only to validation testing (effectiveness test through learning result test and student activity) and dissemination of teaching materials through limited distribution to high school chemistry teachers. Effectiveness test of problem solving module based on learning result of student learning result (post test) using the developed product. Trials were conducted on 31 students.

In addition, the effectiveness test is also carried out through observation to observe the student activity and the course of learning as a whole using problem-solving learning module based on 6 meetings. The observed scopes are reading and analyzing materials, working together and discussing with friends to determine answers to questions, asking teachers, responding to teacher questions / statements, and doing exercises.

The dissemination of teaching materials is done through the distribution to a limited number of teachers. This distribution is intended to obtain responses and feedback on developed learning modules. If the target response, the user of the learning module is good, then the printing is done in large quantities and marketing so that the learning module can be used by the broader target. In this research, researchers distributed learning module based on problem solving in 5 high school chemistry teachers.

\section{Results and Discussion}

\section{Results of Research}

\subsection{Define}

This step consists of several stages: first, front end analysis. This front-end analysis stage is interviewed of 10 high school students who have studied stoichiometry. Based on the results of interviews with students, it can be concluded that the main problems that occur in schools related to teaching materials used so far less involving students actively in the learning process in understanding stoichiometry. Therefore, it takes a teaching material that can improve the understanding of student concept and not only used to confirm the concept alone, it can attract students' interest to learn, and can make students active. In addition, the required teaching materials are teaching materials that have aspects of three levels of chemical representation (macroscopic, microscopic, and symbolic and the relationship between the three). One of the teaching materials is a module based on problem solving.

Second, student analysis. The purpose of this analysis is to examine the characteristics of students as an illustration for designing teaching materials. Based on the results of interviews and observations in the learning process, it can be known in general outline characteristics of student learning are as follows: 1) students easily forget the concepts they learn if students is not involved in the process of building a conceptual understanding, 2) students prefer teaching materials with short material, it also has an example of how to solve problems related to chemical calculations. This helps students in working on problems related to the material being studied, so students do not memorize the formula in understanding the concept, 3) the students prefer the colored material. According to students the display of less interesting materials (without color) makes students become bored to learn these teaching materials. However, the use of color on teaching materials makes students more enthusiastic to learn the teaching materials. Result of the analysis of the characteristics of students into consideration in the development of teaching materials.

Third, the task analysis conducted basic competence (BC) analysis. Based on the results of analysis BC 3.10 applies the basic laws of chemistry, molecular concepts, chemical equations, mole concepts, and 
substance content to complete chemical calculations and 4.10 process data related to basic chemical laws, mole concepts, and substance levels to complete chemical calculations that is in the syllabus of curriculum 2013, translated into 17 indicators of learning.

Fourth, the concept analysis is the identification of the main concepts on stoichiometry material. The main concepts in the stoichiometry material include the law of conservation of mass, the law of definite proportions, the law of multiple proportions, The law of combining volumes, the law of Avogadro, the relative atomic mass (Ar) and the relative molecular mass (Mr), the concept of moles, the number of particles, molar mass, molar volume, substance content, empirical formulas and molecular formulas, chemical equations, chemical calculations in a reaction equation, limiting reagents and excess reagents, levels and chemical calculations for hydrate compounds.

Fifth, the analysis of learning objectives, based on task analysis and concept analysis can be formulated learning objectives. This analysis is used as the basis for constructing the developed teaching materials.

\subsection{Design}

At this stage a draft of learning modules is produced which is based on the Ministry of National Education which consists of: module title; describes the material contained in the module; procedures or instructional activities that learners must follow to learn modules; competence or sub-competence (indicator) to be achieved upon completion of studying modules; the goal consists of the ultimate goal and the goal between which the learner will achieve after studying the module; the material containing which the students must learn and understand; questions, exercises, and / or tasks to be performed or completed by students; evaluation or assessment that serves to measure the ability of students in mastering the module; key answer from problem.

\subsection{Develop}

At this stage, the assessment is done by the experts through validity test and product development test through practicality test on teachers and students. Revisions are also made based on input from each of the steps of the test conducted. Prior to the product trial, the product of learning module based on problem solving that was generated was validated by some expert. However, previously the data collection instrument that are used, need to be validated first by expert. Based on the result of instrument validation for the validation of learning module based on problem solving, the average $\mathrm{k}$ value (moment kappa) is 0.83 , for teacher practice instrument obtained the average $\mathrm{k}$ value of 0.87 , and for the student practice instrument sheet obtained an average value of $k$ of 0.83 with a category of very high validity. Based on the results of instrument validation analysis, the data collection instrument can be used as an instrument of validation and practicality of learning module based on problem solving. After the revision is done according to the suggestion from the expert, the data collection instrument can be used as an instrument of validation and practicality of learning module based on problem solving.

Assessment of expert aspect is done by considering 4 aspects, namely component of content, presentation (construction), linguistic and graphic. Based on the processing data, the average validity of learning module based on problem solving in stoichiometry developed in Table 1 below shows.

Table 1. Average Test Result Validity of learning module based on problem solving

\begin{tabular}{llc} 
No. & \multicolumn{1}{c}{ Validity tes } & $\begin{array}{c}\text { Average } \mathrm{k} \text { value of } \\
\text { Validator }\end{array}$ \\
\hline 1 & Validity of content & 0,87 \\
\hline 2 & Validitay of construction & 1 \\
\hline 3 & Validity of linguistic & 0,91 \\
\hline 4 & Validity of graphic & 0.93 \\
\hline Average of k value & 0,93 \\
\hline Categories of validity & Very High
\end{tabular}

Based on table 1, it is stated that the result of validity test of learning module based on problem solving obtained the average value of kappa moment $(\mathrm{k})$ of 0.93 with the category of very high validity. Although the validity of the learning module is very high, there are still some components that need to be improved according to the expert's suggestion. 
After the revision, a practicality test is performed. Practicality of learning module based on problem solving seen from the product of the product of limited trial results in the field regarding the practicality and implementation of developed products. Practicality data is obtained from the results of questionnaire analysis of chemistry teacher response and student response questionnaire. Following analysis from questionnaire response from teacher can be seen in Table 2 .

Table2. Practical Test Results of Teacher Response Questionnaire

\begin{tabular}{lccc}
\hline No. & Aspect & $\begin{array}{c}\text { Kappa } \\
\text { Moment } \\
(\mathrm{k})\end{array}$ & $\begin{array}{c}\text { Categories of } \\
\text { Practicality }\end{array}$ \\
\hline 1. & Ease of use of learning modules & 0,93 & Very High \\
\hline 2. & Construction & 0,82 & Very High \\
\hline 3. & Ease of interpreting & 0,80 & High \\
\hline & Average of kappa moment & 0,85 & Very high \\
\hline
\end{tabular}

Based on table 2, the assessment of the practicability of learning module based on problem solving is very high with the kappa moment value of 0.85 . From the results of this practice, then the module can be applied to the learning process in school. Although the practicality of the learning module is very high, there are still some components that need to be improved. The teacher suggested that the module should be added to more practical formulas in studying stoichiometry material.

Practicality of learning module based on problem solving is also seen the result of questionnaire analysis of student response to module. Here is an analysis of the questionnaire can be seen in Table 3 .

Table3. Practical Test Results of Student Response Questionnaire

\begin{tabular}{cccc}
\hline No. & Aspect & $\begin{array}{c}\text { Kappa } \\
\text { Moment } \\
(\mathrm{k})\end{array}$ & $\begin{array}{c}\text { Categories of } \\
\text { Practicality }\end{array}$ \\
\hline 1. & Ease of use of learning modules & 0,78 & High \\
\hline 2. & Construction & 0,79 & High \\
\hline 3. & Ease of interpreting & 0,75 & High \\
\hline & Average of kappa moment & 0,77 & High \\
\hline
\end{tabular}

Based on the assessment data in table 3, learning module based on problem solving obtained high practicality level. This can be seen from the average acquisition of kappa moment of all assessed aspects that reaches 0.77 with high practicality category.

\subsection{Desseminate}

The dissemination is done in this study is limited only to validation testing (effectiveness test through learning result test and student activity) and dissemination of teaching materials through limited distribution to high school chemistry teachers. Effectiveness test of problem solving module based on learning result of student learning result (post test) using the developed product. Trials were conducted on 31 students. Percentage mastery of student learning can be seen in table 4 below.

Table 4. Student Learning Results

\begin{tabular}{|c|c|c|c|}
\hline Completeness (\%) & $\begin{array}{c}\text { Quantity of completed } \\
\text { students }\end{array}$ & $\begin{array}{c}\text { Quantity of } \\
\text { unfinished students }\end{array}$ & Average value \\
\hline 67,74 & 21 & 10 & 75,61 \\
\hline
\end{tabular}

Based on the data in table 4, learning after using problem solving-based learning module can be said to be effective because it is more than $60 \%$ of students whose learning outcomes are above the minimum completeness criteria (MCC) of $67.74 \%$ of students as many as 21 people.

In addition, the effectiveness test is also carried out through observation to observe the student activity and the course of learning as a whole using problem-solving learning module based on 6 meetings. The observed scopes are reading and analyzing materials, working together and discussing with friends to determine answers to questions, asking teachers, responding to teacher questions / statements, and doing 
exercises. Results of observation of learning activities at the first meeting until the sixth meeting were $77.5 \%, 87.34 \%, 87.59 \%, 87.72 \%, 93.55 \%$ and $96.13 \%$. Based on the calculation, got the percentage of student activity when using problem solving based learning module is $88,31 \%$, which means that student learning activity when using problem solving learning module that is with category very effective.

The dissemination of teaching materials is done through the distribution of a limited number of teachers. This distribution is intended to obtain responses and feedback on developed learning modules. If the target response, the user of the learning module is good, then the printing is done in large quantities and marketing so that the learning module can be used by the broader target. In this research, researchers distributed learning module based on problem solving in 5 high school chemistry teachers. Based on the results of the responses from the 5 teachers it can be concluded that this learning module is good, complete, and motivate students to learn, and can guide students learn the concept of stoichiometry so that students' understanding of the material will increase. In addition, some teachers suggest learning module is coupled matter and sample questions on a particular material, clarified the picture of $\mathrm{H} 2 \mathrm{O}$ and tested on students in several schools of different inputs (schools with categories superior, medium, low) so they will know how much the effectiveness of the learning module is able to increase student learning activity can be measured.

\section{Discussion}

The main product in research and development that has been implemented is a problem-solving learning module on Stoichiometry materials for students of first grade of senior high school. The results of qualified development needs assessment, to determine the quality of development results required three criteria that is the validity, practicality and effectiveness. Assessment of problem solving learning module is done by using a validation sheet that has been validated by 3 experts. Data validation of module on stoichiometry was obtained from the assessment of 2 chemistry lecturers, 1 lecturer of Indonesian language and 1 chemistry teacher of senior high school. 3 lecturers are experts of materials, media and language experts who know the truth of content, language and format of problem solving based learning solving module. While one high school chemistry teacher who knows the possibility of instructional learning using learning-based problem solving chemistry module.

Data assessment of the validation of problem solving module is then analyzed using Kappa Cohen formula. From the data processing obtained the average score of validity of the four experts of 0.93 with a category of very high validity. Thus, the result of the assessment of the developed learning module is valid. Expert gives a valid value because the module developed by the author meets the criteria in accordance with the validation sheet. The problem solving learning module on the resulting stoichiometry material has been feasible to use with improvements in accordance with the advice given by the expert. After that, a revision of the learning module on the stoichiometry material will be developed for further trial.

Practicality of problem solving learning module on stoichiometry material seen from the usage of product from the result of limited trial in the field concerning the practicality and implementation of developed product. From the results of questionnaire assessment teacher response shows that the average score of learning module practicality obtained by 0.85 with very high category. Based on this it is known that the developed learning module is practical school trial.

Teachers provide a very high practical value because the developed learning module meets the criteria according to the teacher's response questionnaire. Practicality considerations can be seen from aspects of ease of use, presentation aspect, and easiness in interpreting (Sukardi, 2011). Viewed from the aspect of its ease of use that module developed facilitate teachers in achieving learning objectives and facilitate teachers to increase student activity in learning. From the presentation aspect that the contents of the material in the module with the accomplished competencies are appropriate and from the aspect of ease in interpreting that the learning module of problem solving is easily interpreted by the teacher. So, with the learning module, teachers can be more practical and focused in teaching the students. In other words that problemsolving learning module can be said to be practical if the module can be used easily by teachers and students in learning.

Overall questionnaire responses given to students on the problem-solving learning module gets very good response. Practical instrument valuation data from student response questionnaire obtained the average value of kappa moment of 0.77 . It is revealed that the resulting learning module has a high practicality category to be used in the learning process. The use of the learning module with color and design on the picture is very helpful for students interested to learn. The high interest or attention of 
students can occur because students feel helpful in understanding the concept with the existence of materials and examples of problems that guide students in answering questions, drawings and illustrations are interesting and communicative help students to better understand the material being studied.

A good response is also seen in their ability to solve problems. At the beginning of the meeting, they still need to be guided in solving the questions given to the module. However, at subsequent meetings the students have begun to be able to solve the problems according to the stages being done. The student asks the teacher to check whether the problem-solving steps they have been working are correct. The teacher acts as a facilitator who will correct the student answers and straighten out if there is an inappropriate answer and provide a plus for students who can quickly and accurately answer the questions that exist in the module. Students can follow the lesson using a model of learning well, ability students in problem solving are better and students are encouraged to think critically and creatively (Rochmad, 2012).

The module effectiveness test is intended to determine the efficacy of the module if used in the lesson. Based on data analysis can be concluded that already more than $60 \%$ of students whose learning outcomes are above the MCC that is as much as $67.74 \%$ (21 people). Based on this, the module is effectively used in the learning process. Learning is said to be effective if the student's grade after learning earns a value above the MCC of more than or equal to $60 \%$ (Budimah et al., 2014). Student achievement using problem solving module is said to be effective with an average of 75.61 above MCC (75). By involving students to solve problems so that students have a high response in solving problems presented, students want to explore with a variety of learning experiences or even through the debate so that this will affect student achievement because it has experience solving problems (Duong, 2012).

When students are given a module, students must be willing to try their own to understand the material they learn first independently. That way, students can solve problems easily and can ask questions about material that they do not understand and become more active during learning. Problem solving does not expect students to just listen, record and then memorize the subject matter, but through problem solving students are actively thinking, communicating, searching and processing data and concluding (Sanjaya, 2008). Problem solving can improve student's learning achievement because students are encouraged to solve the problems in learning independently so that students can find solving problems that are sought (Carolin et al., 2015).

Knowledge that student acquire on their own constructions with the help and guidance of teachers. In accordance with the theory which explains that the knowledge that students obtain on their own construction will last longer in the memory of students, especially when students are given the opportunity to construct their own, means that many senses are active in receiving information. This means that the concepts studied are attached to the student and stored in long term memory, rather than the knowledge that students receive without learning experience (Jalius, 2009).

The average result of student activity learning activity get the percentage of student activeness when using problem solving based learning module is $88,31 \%$, which means that effectiveness of using problem solving module based on problem solving that is with "very effective" category. Based on the observer's observation, it is concluded that in the learning process using the use of problem solving based learning module, the students look enthusiastic and active. When using the learning module, students appear to start by reading the material, observing and analyzing sample questions, discussing questions, and doing formative exercises and tests.

Student activity is low at the first meeting. This is because students and teachers are still adaptation using the module. At this first meeting, there are still many students who are confused to answer the question even though it has been explained by the teacher through example problem. As a result at this first meeting the learning process takes a longer time. For the next meeting, the learning activities continue to increase from the first meeting. This is because the students have started to know and accustomed to answer questions with the guidance of teachers. The role of teachers during problem solving learning activities is to guide students from identifying problems, performing problem-solving planning, implementing plans that have been made up to evaluate the results of problem solving (Wena, 2009).

The problem solving learning model of Polya begins with giving problem / question. Problem given in the form of question that lead to the concept. Students practice understanding problems, compile and execute strategies in solving problems to draw conclusions. The teacher guides the students in each step so students understand the concept well. With these steps, the problem solving model of Polya is very appropriate to be 
applied as a solution to improve students' ability in solving mathematical problems, one of them is stoichiometry.

\section{Conclusion}

Based on the results of the development, and experiments that have been done, researcher can conclude several things, as follows.

State your conclusions clearly and concisely. Be brief and stick to the point;

1. Learning module based on problem solving has been produced on stoichiometry material for 1st grade of senior high school chemistry learning which is designed by using problem solving learning cycle according to Polya and packed with 3 levels of chemical representation (macroscopic, microscopic, and symbolic).

2. The learning module that has been created in this development study has:

1.5. The category of validity is very high with the average value of kappa moment of 0.93

1.6. The category of practicality is very high with the average value of kappa moment value of 0.87 for teacher response questionnaire and high with an average score of 0.77 for student response questionnaire.

Effective category based on the value of students who have scored above the MCC as much as $67.74 \%$ as many as 21 people and also in terms of student activity obtained data of $88.31 \%$ with the very effective category.

\section{Acknowledgment}

The author would like to thank to Mr. Alizar, S.Pd, M.Sc, Ph.D, Dr. Indang Dewata, M.Si, Mrs. Ratnawulan, M.Si and all parties who have assisted in completing the research and preparation of this article.

\section{References}

Alfaris, Salman. (2014). Application of Problem Solving Polya version on the subject of circle and wide circle. Journal of Mathematics Education of STKIP PGRI Sidoarjo, 2, (1), ISSN: 2337-8166. http://lppm.stkippgri-sidoarjo.ac.id/files/Penerapan-Pembelajaran-Problem-Solving-Versi-Polya-PadaPokok-Bahasan--Keliling-Dan-Luas-Lingkaran.pdf

Bilgin, Ibrahim. (2005). The Effect of Different Problem-solving Strategies on University Students' Problem-solving Achievements of Quantitative Problems in Chemistry. Journal of Educational Sciences: Theory \& Practice, 5 (2), 628-63.

Budimah, Herpratiwi, and Undang Rosidin. (2014). Development of Science Module Character Based Learning Character Material Height in 1st Grade of Junior high School in Bandar Lampung. Jurnal of Science and Education, 1 (1), 1-8. https://media.neliti.com/media/publications/193466-IDpengembangan-modul-pembelajaran-ipa-berb.pdf

Carolin, Yuvencia, Sulistyo Saputro and Agung Nugroho Catur Saputro. (2015). Application of Problem Solving Learning Method Equipped with Student's Worksheet to Increase Activity and Achievement Learning on Basic Chemistry Material Student of 1st grade in Karya 2 Boyolali Senior High School Lesson Year 2014/2015. Journal of Chemistry Education (JPK), 4 (4), 46-63. https://media.neliti.com/media/publications/123765-ID-penerapan-metode-pembelajaran-problem$\underline{\text { so.pdf }}$

Devi, Poppy Kamalia. (2015). Training Material Implementation of 2013 Curriculum for Senior High School Year 2015. Jakarta: Human Resources Development Agency Education and Culture and Quality Assurance of Education Ministry of Education and Culture. 
Duong, Minh Quang. (2012). Analitical Evaluation of College Learning Expeiences on Students' ProblemSolving Efficacy among Technical and Scientific Areas. International Journal of Evaluation and Research in Education (IJERE), 1(2), 67-72.

Jalius, Ellizar. (2009). Development of Learning Program. Padang: UNP Press.

Komariah, Kokom. (2011, June). Application of Problem Solving Polya Model to Improve Problem Solving Ability For 3rd grade of Junior High School Students in Cimahi. Proceedings of National Seminar on Research, Education and Implementation of Mathematics and Natural Sciences, Faculty of Mathematics and Natural Sciences, University of Yogyakarta. Retrieved June 29 ${ }^{\text {th }}$ 2016, from: http://eprints.uny.ac.id/7195/1/PM-25\%20-\%20Kokom\%20Komariah.pdf

Prastowo, A. (2012). Creative Guide Creating Innovative Instructional Materials. Jogjakarta: Diva Press.

Rochmad. (2012). Design of Mathematical Learning Device Development Model. Journal of Kreano, 3 (1), 59-72. http://download.portalgaruda.org/article.php?article=136826\&val=5678\&title=Des

Sanjaya, Wina. (2008). Strategy of Learning-Oriented Standard Process of Education.Jakarta: Kencana.

Sugiyono. (2011). Educational Research Methods. Bandung: Alfabeta.

Sukardi. (2011). Evaluation of Education, Principles, and Operations. Yogyakarta: Bumi Aksara.

The Ministry of National Education. (2008). Technical guidance of High School Material Development. Jakarta : Directorate of High School Development.

Thiagarajan, Sivasailam, Dorothy S. Semmel, dan Melvyn I. Semmel. (1974). Instructional Development for Training Teachers of Exceptional Childern a Sourcebook. Indiana: Indiana University Bloomington.

Wena, M. (2009). Contemporary Innovative Learning Strategy: An Operational Conceptual Overview. Jakarta: BumiAksara. 